\title{
KECERDASAN IQ, EQ DAN SQ \\ DALAM PEMBENTUKAN KEPRIBADIAN MUKMIN
}

\author{
Ismail \\ STAI Nazhatut Thullab Sampang \\ e-mail: yajlis_ismail@yahoo.com
}

\begin{abstract}
Abstrak:
Penelitian ini merupakan kajian teoritis tentang kecerdasan yang dimiliki oleh manusia yang kemudian dengan kecerdasan itu dapat mengarahkan dirinya untuk memiliki kepribadian, karena kecerdasan dapat diartikan sebagai sebuah kecakapan yang dimiliki oleh seorang individu. Beberapa pendapat mengatakan bahwa di dalam diri manusia tidak hanya kecerdasan intelektual (IQ), melainkan juga terdapat kecerdasan emosi (EQ) dan kecerdasan spiritual (SQ). Sehingga pertumbuhan dan perkembangan individu manusia akan selalu dipengaruhi oleh pertumbuhan dan perkembangan ketiga jenis kecerdasan itu sendiri. Keseimbangan pertumbuhan dan perkembangan ketiga kecerdasan itu akan berakibat pada keseimbangan pertumbunhan dan perkembangan kepribadian. Dalam kajian ini penulis akan menjelaskan korelasi antara IQ, EQ \& SQ dalam pembentukan pribadi mukmin, serta bagaimana proses pembentukan pribadi mukmin.
\end{abstract}

Kata Kunci: IQ, EQ, SQ, Pribadi Mukmin

\begin{abstract}
:
This study is a theoretical study of intelligence possessed by the human intellect then it can lead a person to have a personality, as intelligence can be defined as a skill possessed by an individual. Some opinions say that in a human being is not just intellectual intelligence (IQ), but there are also emotional intelligence (EQ) and spiritual intelligence (SQ). So that the growth and development of the human individual will always be influenced by the growth and development of three types of intelligence itself. Balance growth and development of the three intelligence will result in the balance and personality development. In this study the authors will describe the correlation between IQ, EQ and SQ believer in personal formation, and how the process of personal formation believer.
\end{abstract}

Keyword: IQ, EQ, SQ, Personal Believer. 


\section{Pendahuluan}

Ilmu pengetahun yang selalu tumbuh dan berkembang memberikan pengaruh terhadap kehidupan manusia secara teoritis maupun praktis. Perkembangan tersebut berjalan seiiring dengan kemajuan yang dapat dicapai oleh manusia melalui jalan berfikir dan tentunya pula dengan eksperimen dalam rangka pembuktian suatu penemuan baru.

Begitu juga dengan permasalahan kecerdasan manusia, yang merupakan karunia dari Allah SWT, agar dipergunakan untuk menjalankan segala ketentuan yang ditetapkan dan diwajibkan kepada setiap manusia di dalam kehidupan di dunia ini. Kecerdasan manusia menurut disiplin ilmu psikologi terutama telah mengalami perubahan. Pada era yang lalu, diketahui bahwa kecerdasan yang dimiliki oleh manusia hanyalah kecerdasan akal, atau yang biasa diistilahkan dengan Intelectual Quotient (kecerdasan intelektual). Namun pada perkembangannya, di era sekarang telah ditemukan bahwa di dalam diri setiap manusia tidak hanya kecerdasan intelektual, tetapi terdapat juga kecerdasan emosional (Emotional Quotient) dan kecerdasan spiritual (Spiritual Quotient).

Sehingga pada masa sekarang yang sering disebut oleh para ahli adalah $I Q, E Q$ dan $S Q$, yang mana ketiga-tiganya merupakan suatu kesatuan yang tersimpan di dalam diri setiap orang serta harus dapat tumbuh dan berkembang dengan seimbang untuk menjalani kehidupan dengan seimbang pula. Sebagaimana firman Allah Swt. :

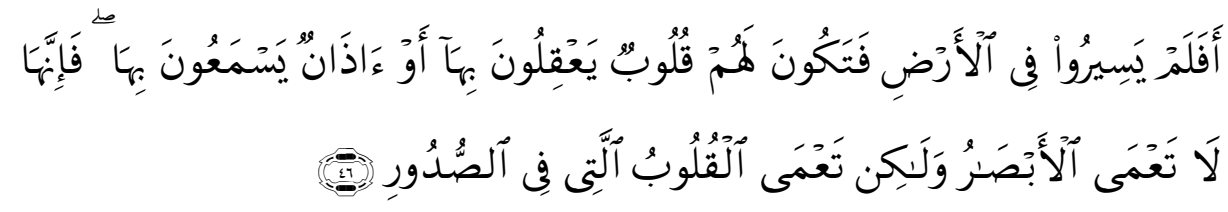

Artinya : "Maka apakah mereka tidak berjalan di bumi, lalu jadilah mereka mempunyai hati yang mereka pergunakan untuk memahami, atau mempunyai telinga yang mereka pergunakan untuk mendengar? Karena sesungguhnya bukanlah mata yng buta, tetapi hati yang ada di dalam dada itulah yang buta" 1

Untuk mendalami tentang kecerdasan manusia, maka berikut ini akan penulis sajikan penjelasannya satu persatu.

${ }^{1}$ QS. Al-Hajj (22), : 46.

Ismail Kecerdasan 


\section{Kecerdasan Intelektual (IQ)}

Sebelum penulis membahas definisi kecerdasan intelektual menurut para ahli, perlu kiranya kita pahami ayat al-Qur'an :

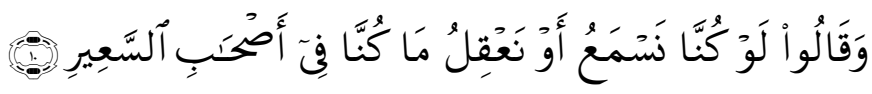

Artinya : "Dan mereka berkata, 'Kalaulah kami mendengar atau memahami, tentu tidaklah kami termasuk para penghuni neraka yang menyala-nyala'."2

Ayat di atas telah menjelaskan bahwa ada keterkaitan yang erat antara indera (pendengaran) dengan akal yang dipergunakan dalam proses berfikir yang kemudian menunjukkan intelektualitas.

Tentang pengertian kecerdasan intelektual disamakan dengan intelek dan disamakan dengan inteligensi, yang mana pengertian tentang intelignesi ini sendiri sangat banyak kita temukan yang telah dikemukakan oleh para ahli, antara lain :

Ebbinghaus (1897) memberi definisi inteligensi sebagai kemampuan untuk membuat kombinasi. Terman (1921) memberi definisi inteligensi sabagai kemampuan untuk berfikir abstrak. Thorndike memberi definisi inteligensi sebagai hal yang dapat dinilai dengan taraf ketidaklengkapan dari pada kemungkinankemungkinan dalam perjuangan hidup individu. ${ }^{3}$

Pengertian di atas menunjukkan pengertian tentang inteligensi umum, karena menurut konsepsi daya inteligensi adalah persatuan (kumpulan yang dipersatukan) daripada daya-daya jiwa yang khusus.

Kata inteligensi berasal dari kata Latin "inteligere" yang berarti menghubungkan atau menyatukan satu sama lain (to organize, to relate, to find together). Istilah ini pertama kali diperkenalkan oleh seorang ahli psikologi Inggris, Charles Spearmen, 1904. Adrew Crider megatakan bahwa inteligensi itu bagaikan listrik, gampang untuk diukur tapi hampir mustahil untuk didefinisikan. Woodworth mengemukakan bahwa inteligensi adalah suatu tindakan yang bijaksana dalam menghadapi setiap situasi secara cepat dan tepat. Stern berpendapat bahwa inteligensi adalah adanya daya menyesuaikan diri dengan keadaan baru dengan mempergunakan alat-alat berfikir manururt tujuannya.

\footnotetext{
${ }^{2}$ QS. Al-Mulk (67), : 10.

${ }^{3}$ Sumadi Suryabrata, Psikologi Pendidikan, (Jakarta, RajaGrafindo Persada), 125
} 
Sedangkan H.H. Goddard mendefinisikan inteligensi sebagai tingkat kemampuan pengalaman seseorang untuk menyelesaikan masalahmasalah yang langsung dihadapi dan untuk mengantisipasi masalah-masalah yang akan datang. Walters dan Gardner mendefinisikan inteligensi sebagai suatu kemampuan atau serangkaian kemampuan-kemampuan yang memungkinkan individu memecahkan masalah atau produk sebagai konskuensi eksistensi suatu budaya tertentu. Sedangkan Flynn mendefinisikan inteligensi sebagai kemampuan untuk berfikir secara abstrak dan kesiapan untuk belajar dan pengalaman. ${ }^{4}$

Binet (1857-1911) berpendapat bahwa inteligensi merupakan kemampuan yang diperoleh melalui keturunan, kemampuan yang diwarisi dan dimiliki sejak lahir dan tidak terlalu banyak dipengaruhi oleh lingkungan. Dalam batas-batas tertentu lingkungan turut berperan dalam pembentukan kemampuan inteligensi. Sedangkan Wechler (1958) merumuskan inteligensi sebagai "keseluruhan kemampuan individu untuk berfikir dan bertindak secara terarah serta kemampuan mengolah dan menguasai lingkungan secara efektif. ${ }^{5}$

Kutipan Crow \& Crow. Menurut L. M. Terman dalam. Intelegensi adalah kesanggupan berfikir dalam arti memikirkan hal-hal yang bersifat abstrak. ${ }^{6}$ Menurut Stern: Intelegensi adalah kapasitas umum dari seorang individu yang dapat dilihat pada kesanggupan pikirannya dalam mengatasi tuntutan kebutuhan yang baru, keadaan rohaniah secara umum yang dapat disesuaikan dengan problema-problema dan kondisi-kondisi yang baru di dalam kehidupan. ${ }^{7}$ Sedangkan menurut Thorndike, intelegensi merupakan kesanggupan dalam memberi sambutan-sambutan yang baik dari sudut pandangan benar atau adanya. ${ }^{8}$ Menurut Stoddard, intelegensi adalah ebilitas yang mengendalikan aktivitasaktivitas dengan ciri (1) sukar, (2) kompleks, (3) abstrak, (4)

4 Tristiadi Ardi Ardani, Psikiatri Islam (Malang, UIN-Malang Press, 2008), 168170

${ }^{5}$ H. Sunarto, \& B. Agung Hartono, Perkembangan Peserta Didik (Jakarta, Rineke Cipta, 1999), 100.

${ }^{6}$ Lester D. Crow \& Alice Crow, Educational Psychology, Buku 1, Penerj. Z. Kasijan (Surabaya, Bina Ilmu, 1984), 205. Definisi ini tampaknya sangat dibatasi, namun di dalamnya ada persamaan dengan titik pandangan Binet, yang mengemukakan interpretasi intelegensi dengan kata sebagai berikut : "Memahami, berpendapat, mengontrol dan mengritik-intelegensi memuat keempat perkataan ini."

${ }^{7}$ Ibid. 205.

8 Ibid. 206. 
ekonomis/tepat, (5) bertujuan, (6) bernilai sosial, dan (7) menampakkan adanya keaslian (penemuan baru), dan untuk mempertahankan kegiatan-kegiatan seperti itu dalam kondisi yang memerlukan konsentrasi energi dan berlawanan dengan kekuatankekuatan emosional. ${ }^{9}$

Dari sekian pengertian di atas dapat diketahui bahwa inteligensi di dalam pengertiannya mempunyai beberapa unsur antara lain daya, kemampuan, kemampuan berfikir dan tingkah laku. Sehingga dapat disimpulkan bahwa inteligensi menggambarkan kemampuan seseorang di dalam berfikir dan atau bertindak / tingkah laku. Inteligensi selalu dikaitkan dengan adaptasi organisme terhadap lingkungannya. ${ }^{10}$

\section{Teori-Teori Inteligensi}

Terdapat beberapa teori yang menjelaskan inteligensi, antara lain :

a. Teori Alfert Binet. Binet mengemukakan bahwa inteligensi bersifat monogenetic, yaitu berkembang dari satu faktor satuan atau faktor umum (g). Jadi untuk dapat melihat seseorang apakah cukup inteligen atau tidak cukup dapat diamati dari cara kemampuannya untuk mengubah arah tindakannya aitu apabila perlu. ${ }^{11}$

b. Teori Edward Lee Thorndike. Thorndike menyatakan bahwa inteligensi terdiri atas berbagai kemampuan spesifik (s) yang ditampakkan dalam wujud prilaku inteligen. Oleh karena itu teorinya dikategorika ke dalam teori inteligensi faktor ganda. ${ }^{12}$

c. Teori Charles E. Spearmen. Spearmen menemukan bahwa tingkah laku manusia itu disebabkan oleh dua faktor, yaitu (1) Faktor umum (general factor / g), dan (2) faktor khusus (special factor/s). Faktot g berfungsi pada setiap tingkah laku, sedangkan s berfungsi pada tingkah laku tertentu saja. Teori ini dapat dilambangkan sebagai berikut :

Tingkah laku $1=\mathrm{Tl} 1=\mathrm{g}+\mathrm{s} 1$

Tingkah laku $2=\mathrm{Tl} 2=\mathrm{g}+\mathrm{s} 2$

\footnotetext{
9 Ibid. 206-207.

10 B.R. Hergenhahn \& Matthew H. Olson, Theories Of Learning, Penerj. TriwibowoBS. (Jakarta, Kencana, 2009), 498

11 Tristiadi Ardi Ardani, Psikiatri Islam...., 172

12 Tristiadi Ardi Ardani, Psikiatri Islam..., 173. Lihat juga. Crow \& Crow, Educational Psychology, Buku 1, Penerj. Z. Kasijan (Surabaya, Bina Ilmu, 1984), 209
} 
Tingkah laku $3=\mathrm{Tl} 3=\mathrm{g}+\mathrm{s} 3$

Tingkah laku $4=\mathrm{Tl} 4=\mathrm{g}+\mathrm{s} 4$

Tingkah laku $5=\mathrm{Tl} 5=\mathrm{g}+\mathrm{s} 5$

Selanjutnya Spearmen mengatakan bahwa faktor g tergantung pada dasar, sedangkan faktor s dipengaruhi oleh pengalaman (lingkungan, pendidikan). ${ }^{13}$

d. Teori Thomson. Menurut Thomson tingkah laku manusia hanyalah disebabkan oleh faktor khusus yang bermacammacam (faktor s). Faktor $\mathrm{s}$ ini tidak tergantung kepada keturunan atau dasar, melainkan tergantung kepada pendidikan. Adanya anak dari golongan atas lebih cerdas dari golongan rendah, bukan karena dasar melainkan karena mereka lebih banyak mempunyai kesempatan untuk belajar. ${ }^{14}$

e. Teori Cyrill Burt. Tiap tingkah laku menurut Burt dimungkinkan oleh tiga macam faktor, yaitu faktor $\mathrm{g}$ (generalfactor), faktor c (common faktor) faktor khusus (special factor $)^{15}$. Dengan ilustrasi:

Tingkah laku $1=\mathrm{Tl} 1=\mathrm{g}+\mathrm{cx}+\mathrm{s} 1$

Tingkah laku $2=\mathrm{Tl} 2=\mathrm{g}+\mathrm{cx}+\mathrm{s} 2$

Tingkah laku $3=\mathrm{Tl} 3=\mathrm{g}+\mathrm{cx}+\mathrm{s} 3$

Tingkah laku $4=\mathrm{Tl} 4=\mathrm{g}+\mathrm{cx}+\mathrm{s} 4$

Tingkah laku $5=\mathrm{Tl} 5=\mathrm{g}+\mathrm{cx}+\mathrm{s} 5$

Teori Thurstone. Tokoh mengatakan bahwa tidak ada faktor $\mathrm{f}$ (general factor), yang ada hanyalah faktor c (common factor) dan faktor s (special factor). Adapun faktor c meurut Thurstone ada tujuh macam yaitu : (1) faktor ingatan $M$ (memory) (2) faktor verbal $\mathrm{V}$ (verbal) (3) faktor bilangan $\mathrm{N}$ (Number) (4) faktor kelancaran kata-kata W (wordfluency) (5) faktor penelaran R ( Reasoning)(6) faktor persepsi P (Perception) (7) faktor ruang $\mathrm{S}$ (Spatial). Kalau sekiranya ada kecakapan umum, itu bukan karena adanya faktor g, melainkan karena kombinasi daripada faktor c tersebut. ${ }^{16}$

Sedangkan tinggi rendahnya kecerdasan intelektual seseorang dipengaruhi oleh beberapa faktor yaitu pembawaan, kematangan, lingkungan dan minat. ${ }^{17}$

\footnotetext{
13 Sumadi Suryabrata, Psikologi Pendidikan..., 128-129

${ }^{14}$ Ibid, 128

15 Sumadi Suryabrata, Psikologi Pendidikan ...,128

16 Ibid, 129-130

${ }^{17}$ Ramayulis, Psikologi Agama (Jakarta, Kalam Mulia, 2002), 87
}

Ismail Kecerdasan 


\section{Pengukuran Inteligensi}

Untuk mengetahui persoalan pengukuran inteligensi, maka perlu didahului dengan sejarah tes (pengukuran) inteligensi itu sendiri. Perkembangan tes inteligensi melalui empat fase, yaitu :

a. Fase persiapan, yaitu di mana para ahli sedang mencari/berusaha mendapatkan tes inteligensi. Fase ini berlangsung kira-kira sampai tahun $1915 .^{18}$

b. Fase naif, yaitu di mana orang menggunakan tes inteligensi yang telah tersusun tanpa mengingat kelemahan-kelemahan yang mungkin terkandung di dalamnya. Fase ini dari kurang lebih 1915-1935. ${ }^{19}$

c. Fase pencarian tes yang bebas dari kebudayaan (culture free test). Tokoh yang terkenal dalam usaha ini adalah Florence $\mathrm{L}$ Goodenough dan Porteus. Goodenough terkenal dengan DAM tesnya (Draw a Man test). Dia berpendapat, bahwa aktivitas anak yang mencerminkan inteligensinya, yang tidak dipengaruhi oleh kebudayaan, adalah menggambar. Sedagkan Porteus dikenal dengan tes labirin. Fase ini berlangsung kirakira tahun 1935-1950.20

d. Fase kritis, yang mlai kira-kira 1950 dna berlangsung terus hingga sekarang. Dalam fase ini para ahli mengakui bahwa tes inteligensi adalah alat yang sangat baik dan berguna, akan tetapi daya gunanya terbatas. Tes iteligensi mengandung kelemahan-kelemahan, antara lain tergantung kepada kbudayaan, hanya cocok untuk jenis tingkah laku tertentu, hanya cocok untuk tipe kepribadian tertentu dan masih banyak kelemahan lainnya. ${ }^{21}$

Selanjutnya, untuk mengukur inteligensi seseorang dapat digunakan model tes Binet dan tes Wechsler.

a. Tes Binet

Tes inteligensi model ini ditemukan oleh Alferd Binet. Hasil pertama-tama daripada usaha Binet dikeluarkan pada tahun 1905. Wujudnya masih sangat sederhana, yaitu terdiri dari 30 item. Untuk memperbaiki model ini Binet melakukan penyempurnaan, yang kemudian mendapat bantuan dari Simon. Hasil usaha lanjutan ini kemudian diterbitkan pada tahun 1908 dnegan nama tes Binet -

\footnotetext{
18 Sumadi Suryabrata, Psikologi Pendidikan, ..., 136

${ }^{19}$ Sumadi Suryabrata, Psikologi Pendidikan, ..., 136

${ }^{20}$ Ibid, 136-137

21 Ibid, 140-146
} 
Simon. Hasil penyempurnaan itu terletak pada penggunaan tes ini yang tidak hanya untuk anak-anak melainkan dapat digunakan untuk umur 3 - 15 tahun. Pada tahap berikutnya, yaitu tahun 1911 diperoleh rumusan perbandingan kecerdasan atau inteleigence quitient yang biasa disingkat $I Q$. Jadi perbandingan kecerdasan itu = kecerdasan dibanding dengan umur kalender (IQ=MA:CA), yang biasa ditulis :

$$
\mathrm{IQ}=\frac{\mathrm{MA}}{\mathrm{CA}} \times 100
$$

Kemudian pada tahun 1916 terbitlah revisi tes tersebut yang dilakukan oleh L.M. Terman, yang dikenal dengan Stanford Revision Tes, atau Stanford - Binet Scale. Pada 1937 Terman dibantu oleh M.D. Merril melakukan revisi terhadap tes yang diterbitkan pada tahun 1916, yang kemudian tes terbitan tahun 1937 ini menjadi tes yang banyak dipergunakan. Perkembangan selanjutnya adalah terjadi pada tahun 1960, yang mana tes terbitan terakhir ini yang digunakan hingga sekarang.22

b. Tes Wechsler.

Karena tes model Binet memang disusun untuk anak-anak, walaupun di dalamnya dimasukkan item-item untuk orang dewasa, tetapi tes Binet tidak memperhitungkan menurunnya inteligensi. Maka Wechsler pada tahun 1939 menerbitkan tes dengan nama Wechsler Bellevue Intelligence Scale (W-B) dan direvisi pada tahun 1955 dengan nama Wechsler Adult Intelligence Scale (WAIS). ${ }^{23}$

Adapun pada masa sekarang, tes inteligensi dapat diklasifikasikan menjadi : tes kemampuan numerik, verbal, perseptual, spatial, teknikal, analitik dan kecerdasan. ${ }^{24}$

Pengukuran intelegensi sebagimana dijelaskan di atas merupakan pengukuran dengan pendekatan kuantitatif, sedangkan pengukuran dalam pendekatan kualitatif dapat kita lihat di dalam ayat al-Qur'an :

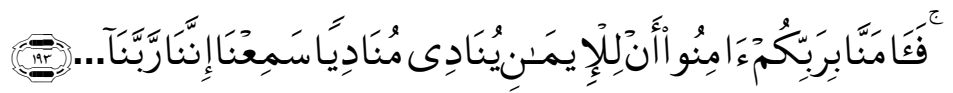

Artinya : "Ya Tuhan kami, sesungguhnya kami mendengar (seruan) yang menyeru kepada iman, (yaitu): Berimanlah kamu kepada Tuhanmu". Maka kamipun beriman...."25

\footnotetext{
22 Sumadi Suryabrata, Psikologi Pendidikan..., 147-153.

23 Ibid, 153-154.

${ }^{24}$ Hardi Sunanto dkk, Memahami Psikotes (Bandung, Pustaka Grafika, 2005), 2425.
} 
Ayat di atas menjelaskan bahwa ukuran kecerdasan dapat dilihat dari respon seseorang atas seruan perintah maupun larangan yang berasal dari Allah. Seseorang yang merespon dengan baik merupakan indikator tinggi rendahnya intelegensinya.

${ }^{25}$ QS. Ali Imron (3), : 193 


\section{Kecerdasan Emosional (EQ)}

Menurut Najati, dalam al-Qur'an dikemukakan gambaran yang cermat tentang berbagai emosi yang dirasakan manusia seperti takut, marah, cinta, senang, antipati, benci, cemburu, hasud, sesal, malu dan benci. ${ }^{26} \mathrm{Hal}$ ini senada ayat al-Qur'an :

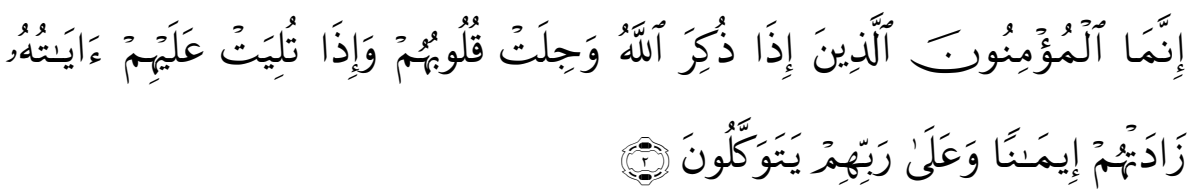

Artinya : "Sesungguhnya orang-orang yang beriman itu adalah orang-orang yang apabila disebut Allah, gemetarlah hati mereka, dan apabila dibacakan kepada mereka ayat-ayat-Nya, bertambahlah keimanan mereka (karenanya) dan kepada Tuhanlah mereka bertawakkal" 27

Menurut Crow \& Crow, emosi adalah suatu keadaan yang mempengaruhi dan menyertai penyesuaian di dalam diri secara umum, keadaan yang merupakan penggerak mental dan fisik bagi individu dan yang dapat dilihat melalui tingkah lau luar. ${ }^{28}$ Sedangkan menurut Salovey dan Mayer, kecerdasan emosi merupakan istilah untuk menggambarkan sejumlah kemampuan mengenali emosi diri sendiri, mengelola dan mengekspresikan emosi diri sendiri dengan tepat, memotivasi diri sendiri, mengenali orang lain dan membina hubungan dengan orang lain. Ciri utama pikiran emosional adalah respons yag cepat tetapi ceroboh, mendahulukan perasaan dari pada pemikiran realitas simbolik seperti kanak-kanak, masa lampau diposisikan sebagai masa sekarang, dan realitas yang ditentukan oleh keadaan. ${ }^{29}$

Kecerdasan emosional merupakan hasil kerja dari otak kanan, sedangkan kecerdasan intelektual merupakan hasil kerja dari otak kiri.

Fungsi, peranan dan perbandingan kedua otak tersebut dapat dilihat pada tabel berikut :

\begin{tabular}{|c|c|}
\hline $\begin{array}{c}\text { OTAK KIRI } \\
\text { (LEFT HEMISPHERE) }\end{array}$ & $\begin{array}{c}\text { OTAK KANAN } \\
\text { (RIGHT HEMISPHER) }\end{array}$ \\
\hline
\end{tabular}

\footnotetext{
26 Muhammad Utsman Najati, Psikologi dalam Al-Qur'an: Terapi Qur'ani dalam Penyembuhan Gannguan Kejiwaan,Penerj. M. Zaka Alfarisi(Bandung: Pustaka Setia, 2005), 99.

27 QS. Al-Anfal (8), : 2.

${ }^{28}$ Lester D Crow \& Alice Crow,Educational Psychology, Buku 1, Penerj. Z. Kasijan (Surabaya, Bina Ilmu, 1984), 116.

${ }^{29}$ Ramayulis, Psikologi Agama ..., 88
} 


\begin{tabular}{|c|c|}
\hline Matematika, Sejarah Bahasa & Persepsi, Intuisi, Imajinasi \\
\hline Konveregen (runtut), Sistematis & Divergen \\
\hline Analitis & Perasaan \\
\hline Perbandingan & Terpadu, Holistic \\
\hline Hubungan & Perasaan \\
\hline Linier & Non Linier \\
\hline Logis & Mistic, Spiritual \\
\hline Scientific & Kreatif \\
\hline Fragment & Rasa, Seni \\
\hline
\end{tabular}

Kecerdasan emosional diakui sebagai suatu kemampuan yang pengaruhnya terhadap individu setara dengan Inteligence Quotient(IQ), dalam pengertian bahwa setiap orang tidak hanya dituntut untuk mengendalikan kecerdasan inteligensi saja atau kecerdasan intelektual saja, namun juga sebenarnya dia harus mempergunkan kecerdasan emosional dalam memnghadapi problem kehidupan yang dijalani. ${ }^{30}$

\section{Aspek-Aspek Kecerdasan Emosional}

Menurut Ari Ginanjar aspek-aspek yang berhubungan dengan kecerdasan emosional dan spiritual, antara lain: konsistensi (istiqamah), kerendahan hati (tawadhu'), berusaha dan berserah diri (tawakkal), ketulusan (ikhlas), totalitas (kaffah), keseimbangan (tawazun) dan integritas penyempurnaan (ihsan). ${ }^{31}$

Sedangkan menurut Goleman, bahwa kecerdasan emosional pada dasarnya memiliki 5 aspek kemampuan, yaitu (1) Kemampuan mengenali emosi diri, (2) kemampuan menguasai emosi diri, (3) kemampuan memotivasi diri, (4) kemampuan mengenali emosi orang lain dan (5) kemampuan mengembangkan hubungan dengan orang lain. ${ }^{32}$

\section{Kecerdasan Spiritual (SQ)}

Menurut Danah Zohar dan Ian Marshal, kecerdasan spiritual adalah kecerdasan untuk mengahadapi persoalan makna atau value, yaitu kecerdasan untuk menempatkan perilaku dan hidup kita dalam konteks makna yang lebih luas dan kaya, kecerdasan

\footnotetext{
${ }^{30}$ Ramayulis, Psikologi Agama ..., 89

31 Ibid, 91

32 Ibid, 91-92
} 
untuk menilai bahwa tindakan atau jalan hidup seseorang lebih bermakna dibandingkan degan yang lain. ${ }^{33}$

Ditinjau dari ilmu saraf, menurut Danah Zohar dan Ian Marshal, semua sifat kecerdasan itu bekerja melalui dan dikendalikan oleh otak beserta jaringan sarafnya di seluruh tubuh. Pengorganisasian saraf yang memungkinkan untuk berfikir rasional, logis dan taat azaz disebut dengan IQ, yang memungkinkan utnuk berfikir assosiatif yang terbentuk oleh kebenaran dan kemampuan untuk mengenali pola-pola emosi disebut dengan EQ, sedangkan yang memungkinkan untuk berfikir kreatif, berwawasan jauh, membuat dan mengubah aturan, menata kembali dan mentransformasikan dua jenis berfikir sebelumnya disebut dengan SQ. ${ }^{34}$

\section{Cara Untuk Meningkatkan IESQ (Kecerdasan Lahir Batin)}

Sebagai sebuah karunia yang diberikan oleh Allah sebagai Sang Khalik, maka manusia dituntut untuk menjaga, merawat dan meningkatkan kemampuan-kemampuan dalam bentuk kecerdasan tersebut. Penting untuk diyakini dengan baik bahwa setiap karunia yang dilimpahkan kepada manusia nantinya akan dimintai pertanggungjwabannya di akhirat, sehingga di dalam pemanfaatan setiap kemampuan itu haruslah menjadikan pemiliknya selamat di dunia dan akhirat. Kemampuan kecerdasan sebagai sebuah potensi tentunya dapat dikembangkan sehingga pengaruhnya terhadap kehidupan semakin lebih optimal.

Menurut Mas Udik Abdullah, di dalam bukunya berjudul Meledakkan IESQ dengan Langkah Takwa dan Tawakkal mengatakan : jika takwa (IQ) dan tawakkal (SQ) baik ( IQ\&SQ baik) akan menjadikan EQ baik. Jika IQ, EQ dan SQ baik, maka IESQ juga baik. Sehingga bisa diambil kesimpulan jika takwa dan tawakkalnya baik atau sempurna, maka IESQ juga baik (cerdas lahir batin). ${ }^{35}$

\section{Kepribadian Mukmin}

Kepribadian di sini dapat dipahami sebagai jumlah keseluruhan tingkah laku individu dalam berbagai situasi sosial. Pengertian tingkah laku di sini meliputi tidak saja perbuatanperbuatan yang tampak dari luar, akan tetapi juga getaran

\footnotetext{
33 Ibid, 93

${ }^{34}$ Ramayulis, Psikologi Agama ...,93

35 Mas Udik Abdullah, Meledakkan IESQ Dengan Langkah Takwa dan Tawakkal (Jakarta, Zikrul Hakim, 2005), 37-41
} 
perasaan yang timbul di dalam diri yang dihasilkan oleh situasi, sebagaimana hal itu dapat diinterpretasi oleh individu melalu introsprksi. ${ }^{36}$ Definisi ini memberikan batasan yang cukup luas bagi kita di dalam memandang tingkah laku individu sebagai kepribadian, yakni tidak hanya tingkah laku yang lahir saja, melainkan gejala-gejala yang terjadi di batin individu juga.

Menurut Ramayulis, kepribadian adalah totalitas sifat manusia baik fisik maupun psikis, yang membedakan antara manusia satu dengan yang lainnya, yang terbentuk karena hasil interaksi dengan lingkungannya. ${ }^{37}$ Artinya bahwa kepribadian merupakan perpaduan antara lahiriyah dengan batiniyah individu yang menjelma menjadi sebuah tingkah laku atau perbuatan.

Sedangkan mukmin merupakan istilah yang diidentifasikan dengan seseorang yang memiliki keyakinan dan kepercayaan terhadap Allah, malaikat Allah, Utusan Allah, Kitab-kitab Allah, Hari kiamat dan qadla' dan qadar. Pembatasan pengertian mukmin seperti di atas untuk memberikan stresshing (penekanan) tentang hakikat iman yang tertanam di dalam hati individu. Manurut Muhammad Utsman Najati, di dalam al-Qur'an ditemukan sembilan pokok ciri orang mukmin ${ }^{38}$, yaitu : pertama ciri yang berkaitan dengan akidah. Meliputi beriman kepada Allah, rasul-rasul-Nya, kitab-kitab-Nya, malaikat-malaikat-Nya, hari kiamat, kebangkitan, hisab, surga dan neraka, hal-hal ghaib serta takdir. ${ }^{39}$ Pada ciri ini, seorang mukmin dapat dilihat dari keyakinannya terhadap berbagai hal yang bersifat ghaib dan di luar batas rasionalnya.

Kedua ciri-ciri yang berkaitan dengan peribadahan. Meliputi beribadah kepada Allah, menunaikan berbagai kewajiban, seperti shalat, shaum, zakat, haji, berjihad di jalan Allah dengan harta dan raga, bertaqwa kepada Allah, senantiasa berdzikir kepada-Nya, beristighfar kepada-Nya, bertawakkal kepada-Nya, membaca alQur'an. ${ }^{40}$ Seorang mukmin dapat dilihat dari konsistensinya dalam melaksanakan perintah Allah serta meninggalkan larangan-Nya baik secara terang-terangan maupun samar. ${ }^{41}$ Ketiga ciri yang

\footnotetext{
36 Lester D Crow \& Alice Crow,Educational Psychology, Buku 1, Penerj. Z. Kasijan (Surabaya, Bina Ilmu, 1984), 264.

37 Ramayulis,Psikologi Agama, (Jakarta, Kalam Mulia, 2009), 108.

38 Muhammad Utsman Najati,Al-Qur'an wa Ilmun Nafsi, Penerj. M. Zaka Al-Farisi Bandung, Pustaka Setia, 2005), 382.

39 Ibid., 383

40 Ibid., 383

41 Ibid., 383
} 
berkitan dengan hubungan sosial, meliputi bermuamalah dengan orang lain secara baik, dermawan dan berbuat baik, bekerja sama, setia kawan dan kooperatif, menyuruh kepada kebaikan dan melarang berbuat kemunkaran, pemaaf, memperhatikan kepentingan orang lain, menghindanri perbuatan sia-sia. ${ }^{42}$ Pada ciri ini, seorang mukimn terlihat memiliki kepekaan sosial yang tinggi terhadap sesama sehingga selalu melibatkan diri dalam upaya yang konkrit bagi kepentingan sosial masyarakat.

Keempat ciri yang berkaitan dengan hubungan keluarga, yakni berbuat baik kepada kedua orang tua dan karib kerabat, bergaul secara baik antara suami-istri, menjaga keluarga dan menafkahinya. ${ }^{43}$ Ciri ini merupakan ciri yang harus dimiliki setiap mukmin sebagai bentuk tanggung jawab dirinya sebagai anggota sebuah keluarga. Tanggung jawab ini tidak bisa diabaikan begitu saja oleh seorang mukmin, karena berkorelasi signifikan dengan kewajiban yang dibebankan oleh Allah.Kelima ciri-ciri akhlak, meliputi bersabar, santun, jujur, adil, amanah, menunaikan janji terhadap Allah dan orang lain, menjaga kehormatan diri, tawadu', tegar dalam kebenaran dan di jalan Allah, memiliki harga diri, kuat kemauan, mengontrol hawa nafsu dan syahwat. ${ }^{44}$ Ciri ini menjadi karakter pribadi mukmin yang menjadi sifat dan tabiat dirinya.Keenam ciri-ciri emosi dan perasaan, meliputi mencintai Allah, takut akan adzab Allah, berharap akan rahmat Allah, mencintai orang lain dan senang berbuat baik kepada mereka, menahan amarah dan mengontrol emosi marah, tidak bertindak dzalim terhadap orang lain, tidak menyakiti mereka, tidak hasud kepada orang lain, tidak ujub dengan diri sendiri, berkasih sayang mencela diri dan merasa menyesal manakala berbuat dosa. ${ }^{45}$ Seorang mukmin harus bisa menguasai emosi dan perasaannya dengan baik sehingga dirinya akan tetap dalam keadaan jiwa yang stabil.

Ketujuh ciri-ciri yang berkaitan dengan pemikiran, meliputi memikirkan kosmos dan ciptaan Allah, menuntut ilmu pengetahuan, tidak memperturutkan prasangka dan mengabaikan kebenaran, memeriksa kebenaran, kebebasan berfikir, dan berkeyakinan. ${ }^{46}$ Mukmin dalam ciri ini menunjukkan sikap ilmiah dan mementingkan ilmu pengetahuan demi kehidupan manusia di

\footnotetext{
42 Ibid., 383

43 Ibid., 383

44 Ibid., 383.

45 Ibid., 383-384.

46 Ibid., 384.
} 
dunia dan akhirat.Kedelapan ciri-ciri yang berkaitan dengan kehidupan praktis dan profesi, antara lain ikhlas dalam bekerja dan menuntaskan pekerjaan, berusaha dengan tekun dan sungguhsungguh dalam rezeki. ${ }^{47}$ Dalam setiap aktifitas praktis dan profesi seorang mukmin selalu menjunjung tinggi etika dan akuntabilitas atas tanggung jawab yang diembannya.Kesembilan ciri-ciri fisik meliputi kuat, sehat, bersih dan higienis. ${ }^{48}$ Mukmin juga tidak meremehkan kebersihan diri, tempat maupun segala sesuatu yang dipergunakan dalam kehidupan sehari-hari demi menjaga kesehatan fisik dan psikis guna beribadah kepada Allah.

Ketika melihat sembilan ciri pokok di atas, seorang mukmin harus memiliki kepribadian yang mencerminkan kemampuannya di dalam membangun pola kehidupannya sebagai makhluk Allah yang wajib menjalankan segala perintah dan menjauhi laranganNya serta fungsi dirinya sebagai bagian dari sosial masyarakat dan lagi dirinya sebagai bagian dari alam semesta.

Dalam konteks pembentukan kepribadian mukmin sebagaimana sembilan ciri pokok di atas, maka perlu diperhatikan bahwa kepribadian mukmin merupakan keseluruhan perilaku dan tingkah laku seseorang yang mencerminkan eksistensi sembilan ciri pokok mukmin sebagaimana dijelaskan di atas. Kepribadian mukmin yang dimaksud tidak akan terbentuk begitu saja, melaikan realisasi kepribadian mukmin tersebut membutuhkan dukungan dan dorongan kemampuan fisik maupun psikis. Kemampuan di sini adalah kecerdasan. Kecerdasan yang konpherhensif, kecerdasan yang tidak hanya mendahulukan intelektual, tetapi juga harus ada kesimbangan dengan kecerdasan emosi dan spiritual. Jika kemudian ada pertanyaan mengapa harus kecerdasan intelektual, emosional dan spiritual harus terkelola dengan baik dalam rangka pembentukan kerpibadian mukmin? Maka dapat dijelaskan bahwa pada sembilan ciri kepribadian mukmin menurut al-Quran yang telah dijelaskan di atas, merupakan kombinasi tiga kemampuan kecerdasan yang dimiliki oleh setiap orang. Al-Qur'an tidak melemahkan salah satunya dan meninggikan yang lainnya, tetapi al-Qur'an memandang sama dari ketiga kecerdasan tersebut sebagai sebuah kompetensi individu yang harus dikelola dengan baik.

\footnotetext{
47 Ibid., 384.
}

48 Ibid., 384. 
Pertumbuhan dan perkembangan kecerdasan-kecerdasan tersebut yang terjadi secara seimbang serta dimanfaatkan untuk kebaikan kehidupan akan dapat mempermudah pembentukan pribadi yang berkarakter dan bertabiat mukmin dengan ciri dan sifat sebagaimana di jelaskan di atas. Sebab seseorang yang hanya cerdas intelektualnya tetapi lemah emosional dan spiritualnya tidak akan dapat membentuk dirinya yang berpribadi mukmin. Hal ini dikarenakan individu tersebut tidak dapat mengelola potensi dirinya serta tidak dapat berprilaku dan bertingkah laku mukmin sejati.

Jika diklasifikasi dari tiga kecerdasan memiliki ranahnya masing-masing dalam ciri kepribadian mukmin. Pertama kecerdasan intelektual meliputi ciri-ciri mukmin yang berkaitan dengan pemikiran, kehidupan praktis dan profesi, dan berkaitan dengan fisik. Kedua kecedasan emosional merupakan ranah ciri mukmin yang berkaitan dengan hubungan sosial, berkaitan dengan hubungan keluarga, berkaitan dengan akhlaq, berkaitan dengan emosi dan perasaan. Ketiga kecerdasan spiritual memiliki ranah ciri mukmin yang berkaitan dengan akidah, dan peribadahan. Ketiga kecerdasan tersebut tidak dapat bekerja sendiri-sendiri dalam pembentukan kepribadian mukmin, melainkan harus selalu terdapat sinergitas agar kepribadian tersebut terbentuk secara komferhensif.

\section{Penutup}

Dari uraian diatas dapat disimpulkan bahwa, setiap manusia memiliki potensi kemampuan yang disebut dengan beberapa kecerdasan. Kecerdasan tersebut antara lain kecerdasan intelektual (IQ), kecerdasan emosional (EQ) dan kecerdasan spiritual (SQ). Ketiga kecerdasan ini sebagai sebuah potensi fisik dan psikis yang dimiliki oleh setiap individu dapat ditingkatkan melalui proses pendidikan dan pengamalan ajaran agama dengan baik, sehingga kecerdasan sebagai salah satu karunia Allah akan terus dipelihara dan ditambah kemanfaatannya. Tiga kecerdasan yang dimiliki oleh setiap individu juga sangat menentukan terhadap kepribadian yang dimilikinya. Jika ketiga kecerdasan tersebut tumbuh dan berkembang secara seimbang serta dimanfatkan pula secara seimbang maka individu tersebut akan dapat membentuk dirinya sebagai pribadi mukmin. Masing-masing kecerdasan memiliki ranahnya sendiri dalam perannya membentuk pribadi mukmin. Ranah kecerdasan intelektual adalah berkaitan dengan pemikiran, kehidupan praktis dan profesi, dan fisik. Ranah kecerdasan 
emosional adalah berkaitan dengan hubungan sosial, hubungan keluarga, akhlaq serta emosi dan perasaan. Ranah kecerdasan spiritual meliputi akidah dan peribadahan.

\section{Daftar Pustaka}

Abdullah, Mas Udik, Meledakkan IESQ Dengan Langkah Takwa dan Tawakkal, (Jakarta: Zikrul Hakim, 2005)

Ardani, Tristiadi Ardi, Psikiatri Islam, (Malang: UIN-Malang Press, 2008)

Crow \&Crow, (Lerter D. Crow \& Alice Crow), Educational Psychologi 1\&2, Penerj. Z. Kasijan, (Surabaya: Bina Ilmu, 1984)

Departemen Agama RI., Al-Qur'an dan Terjemahnya, (Surabaya: alHidayah, 1998)

Hergenhahn, B.R. \& Matthew H. Olson, Theories Of Learning, Penerj. TriwibowoBS, (Jakarta: Kencana, 2009)

Najati, Muhammad Utsman, Al-Qur'an wa Ilmun Nafsi, Penerj. M. Zaka Alfarisi, (Bandung: Pustaka Setia, 2005)

al-Naysabury, Abu al-Husayn Muslim bin al-Hujjaj, Sahih Muslim, (Surabaya: al-Hidayah, $\mathrm{tt}$ )

Ramly, Nadjamuddin, Rahasia dan Keajaiban Kekuatan Otak Tegah,

Tips Mengaktifkan Otak Tengah untuk Mencerdaskan Anak dan Upaya Pendidikan Pencerahan Hidup, (Jakarta: Best Media Utama, 2010)

Ramayulis, H., Psikologi Agama, (Jakarta: Kalam Mulia, 2002)

Sarwono, Sarlito W., Berkenalan Dengan Aliran-Aliran dan Tokoh-

Tokoh Psikologi, (Jakarta: Bulan Bintang, 2002)

Sjarkawi, Pembentukan Kepribadian Anak: Peran Moral, Intelektual,

Emosional, dan Sosial sebagai Wujud Integritas Membangun

Jati Diri, (Jakarta: Bumi Aksara, 2008)

Sunanto, Hardi, dkk, Memahami Psikotes, (Bandung: Pustaka

Grafika, 2005)

Sunarto, H., \& B. Agung Hartono, Perkembangan Peserta Didik, (Jakarta: Rineke Cipta, 1999)

Suparno, Paul, Teori Perkembangan Kognitif Jean Piaget, (Yogyakarta: Kanisius, 2001)

Suryabrata, Sumadi, Psikologi Pendidikan, (Jakarta: RajaGrafindo Persada, 2008)

Syahidin H, Menelusuri Metode Pendidikan dalam Al-Qur'an, (Bandung: Alfabeta, 2009) 